\title{
Invasion: Framing War Protestors at National Conventions
}

\section{Monica Brasted, The College at Brockport, SUNY, USA}

\begin{abstract}
This study examines local press coverage of protests during the 1968 Democratic Convention, the 2004 Republican Convention and the 2008 Republican Convention. As hometown papers for the host cities of national conventions during times of war protests, the Chicago Tribune in 1968, the New York Times in 2004 and the Minneapolis Star Tribune in 2008 had key similarities and differences in their coverage of the protestors. Each paper utilized the protest paradigm to varying degrees in the construction of their stories about the protests. This study found that the Chicago Tribune in 1968 and the New York Times in 2004 developed the theme of an invasion of their respective cities by outsiders who threatened the social order. The newspapers emphasized the threat to social order poised by the protestors through reporting on violation of laws and on the disruption to the everyday lives of city residents. An unexpected finding of this study was that the Star Tribune had significant differences in its coverage compared to the other two newspapers and it varied from the protest paradigm in its coverage.
\end{abstract}

Keywords: protest paradigm; press coverage; protestors; political conventions 
The war in Iraq became an increasingly unpopular war. As the war went on, some began to draw comparisons to the Vietnam War. One area of interest is the ways in which the press coverage of protests against these two wars during National Conventions may have been similar or different. The purpose of this paper is to examine and compare the framing of war protests during the 1968 Democratic Convention, the 2004 Republican Convention and the 2008 Republican Convention.

News framing of protest movements has been an active area of scholarship since the late 1960s. In the process of reporting movement activities, journalists use news frames to "simplify, prioritize and structure the narrative flow of events" (Norris, 1995, p. 357) Entman's (1993) work on the concept of framing produced the following definition of framing in the news:

To frame is to select some aspects of a perceived reality and make them more salient in a communicating context, in such a way as to promote a particular problem, definition, causal interpretation, moral evaluation, and/or treatment recommendation for the item described (p. 52; italics in the original).

According to McLeod and Detenber (1999), "examinations of news content show that news stories about protests tend to focus on the protestors' appearances rather than their issues, emphasize their violent actions rather than their social criticism, pit them against the police rather than their chosen targets, and downplay their effectiveness. This kind of coverage constitutes what has been called the 'protest paradigm' (Chan \& Lee, 1984), which leads to news coverage that supports the status quo" (p. 3). Status quo support in news coverage of social protests has been well documented (Gitlin, 1980; Tuchman, 1978).

McLeod and Hertog (1998) have classified the characteristics of the protest paradigm, which provides a template for the construction of a protest story, into four categories. The first is the narrative structure in which it is common for the journalists to cast the protest as a battle between the protestors and the police, rather than as an intellectual debate between the protestors and those they oppose. The emphasis quite often is on social disorder. The second is the reliance of journalists on official sources and official definitions in protest stories which results in support for the status quo by telling the story from those sources' perspectives. Third is the invocation of public opinion. News stories can convey cues to public opinion 
through opinion polls, overt characterizations, invocation of social norms, violations of laws, and symbolic use of bystanders (McLeod \& Hertog, 1992). Finally, there is the use of frames that de-legitimize, marginalize and demonize the protestors in the protest stories.

In the article, Framing Protest: The Chicago Tribune and the New York Times during the 1968 Democratic Convention (2005) Brasted compared the coverage of the protests in the Chicago Tribune and the New York Times during the 1968 Democratic Convention. In that article, Brasted found that both papers utilized the protest paradigm in their coverage of the protestors. However, framing differences were found to exist. Brasted found that the Tribune told the story of the protests from the perspectives of the Chicagoans in that the stories "framed the events in terms of an invasion of outsiders and a battle by police to maintain social order and protect the citizens of Chicago" (p.21). The protestors were depicted as the enemy of the citizens of Chicago. Brasted found little sympathy for the protestors expressed in the news stories or editorials of the Chicago Tribune. Although the stories in the New York Times adopted the narrative structure of a battle and disruption of the social order, they did not emphasize the theme of an invasion by outsiders.

In the article, Protest in the Media, Brasted (2005) found evidence of the use of the protest paradigm by the New York Times in its coverage of the protests during the 2004 Republican National Convention in New York. This paper will build upon this previous research by comparing the coverage in the Tribune in 1968 with the coverage in the Times in 2004 and the Star Tribune in 2008 to see what similarities and differences exist. As host cities to the conventions in times of protest, one of the main questions to be addressed is whether or not the theme of an invasion by outsiders is present in the 2004 and 2008 coverage.

\section{Research Questions}

The research questions for this study are based on the findings of the previous research discussed. The analysis was guided by the following major questions (RQs):

RQ1. How is the frame of an invasion by outsiders developed in the Chicago Tribune's coverage of the protests of the 1968 Democratic convention?

RQ2. Does the New York Times adopt the theme of an invasion by outsiders in its coverage of the protests of the 2004 Republican convention? 
RQ3. Does the Star Tribune adopt the theme of an invasion of outsiders in its coverage of the protests of the 2008 Republican convention?

RQ4. Does the Star Tribune utilize the protest paradigm in its coverage?

RQ5. What similarities and/or differences exist between the Chicago Tribune's coverage in 1968, the New York Times coverage in 2004 and the Star Tribune's coverage in 2008 ?

\section{Method}

The purpose of this study is to examine and compare the press coverage of the protests during the 1968 Democratic National Convention in Chicago by the Chicago Tribune, the 2004 Republican National Convention in New York City by the New York Times and the 2008 Republican National Convention in Minneapolis by the Star Tribune. A descriptive analysis of content was conducted on news stories that appeared in the Chicago Tribune in 1968, the New York Times in 2004 and the Star Tribune in 2008. News stories concerning the protests, the protestors, the security preparations and the police actions during the conventions that appeared a few days before, during and after each convention were examined. The unit of analysis was the individual news story. Editorials and letters to the editor were also included to determine the paper's position and to get a sense of public opinion. Over one hundred and forty articles were included in the analysis, 61 from the Chicago Tribune, 52 from the New York Times and 33 from the Star Tribune.

\section{Findings}

\section{The Chicago Tribune-1968}

The dominant narrative structure in the stories in the Chicago Tribune about the protests of the Democratic Convention in 1968 was that of battle or conflict. Detailed descriptions of the protestors, police, and National Guard and their actions were included in the stories. The journalists carefully reconstructed the events for the readers providing detailed accounts of march routes. Many of the stories recreated the battle between the protestors and police through the use of warfare metaphors such as battle, charge, attack, retreat, outflanked, and skirmish line.

In addition to the battle theme, the issue of social order also dominated the coverage in the Chicago Tribune. While others, like the New York Times, were criticizing the actions of the police during the 1968 Chicago protests and categorizing them as violence, the Chicago 
Tribune did not. Instead, the actions of the police and National Guard were framed as efforts to restore order. The demonstrators were reported as having disrupted the social order by leaving the park, blocking streets and acting violently toward the police. The Chicago Tribune repeatedly framed the police as protecting the public and maintaining order. The events in Chicago were treated as social disorder news in the Tribune. This theme is even found in the articles leading up to the convention that focused on how the protestors were a threat to order and how the police and National Guard were responsible for maintaining order.

The Tribune also developed this theme of a threat to social order by publishing articles that focused on the violation of laws by the demonstrators. These violations included being in the park past curfew, marching without permits, threatening police, throwing rocks and bottles at police, shouting "kill the pigs", using illegal drugs, and burning draft cards. Brasted (2005) found that in 1968, "the Chicago Tribune ran more articles than the New York Times emphasizing the violent nature of the group and its leaders and the disruption to the social order through the violation of laws" (p.16).

The threat to social order was further underscored in the Tribune by developing the frame of an invasion by outsiders. On August 21, 1968 The Tribune reported that, "A New York City anti-war group will send busloads of demonstrators to Chicago on Monday to take part in two peace marches during the Democratic National convention, THE TRIBUNE learned yesterday" (p.16). Not only did the Tribune report on the influx of protestors to Chicago, but it also reported the increase in the flow of drugs into the city as a result of these outsiders. The Tribune reported the seizure of illicit "drugs that had been brought to Chicago for hippie consumption next week from the west coast, the middle west, and the east coast" (Wiedrich, August 22, 1968 p. 3).

The reliance on official sources, such as Mayor Daley and other government officials, by the Tribune helped to further develop the perception of the protestors as outsiders. In commenting on the City's attempt to help arrange the demonstrations, Daley said,

They have no right to come into the city and tell us what they are going to do. We don't permit our own people to sleep in the park, so why should we let anyone from outside the city sleep in the park. We don't permit our own people to march at night, 
so why should we let a lot of people do snake dances at night thru the neighborhoods (Schreiber, August 23, 1968 p. 11).

After the worst night of violence between protestors and police in Chicago, Mayor Daley, who was responsible for ordering the National Guard to duty, told a reporter, "I didn't invite those people there. We're using the guard to reinforce the police, not move them. I gave the order for the protection of the people of the city of Chicago" ( 800 Guardsmen Face Hippies in Park, August 28, 1968, front page). Again the implication is clear. The protestors are framed as uninvited, unwelcome outsiders.

This position advocated by the official sources is supported in the editorial copy of the Tribune. On August 28, 1968 the editors wrote,

We have no sympathy with the rowdy demonstrations conducted by the hippies, yippies, and other young punks who have gathered in Chicago by the thousands. Their presence is unnecessary for the work of the Democratic national convention, which they apparently are trying to influence. We do have sympathy with the Chicago policemen who have been working 12-hour shifts and getting tired. Particularly they are tired of senseless demonstrations which take them from more important work...THE TRIBUNE has taken the lead in advocating strict enforcement of the laws and has indorsed the decision to summon strong security forces for the Democratic convention (Bad Judgment p. 16).

This editorial supports the framing of the protestors as outsiders who have disrupted the social order in Chicago. The actions of the police are supported because they are presented as an attempt to restore the order disrupted by the protestors.

An editorial the next day, August 29, 1968, further supported the actions of the police by detailing the potential threat that the protestors posed to the social order. According to the Tribune editors,

The precautions were taken because the city received many warnings from radical leftists, student groups, and black power zealots. They threatened to have a million or more demonstrators here for the purpose of disrupting the convention and the life of the city. Some of the groups had plans to ignite widespread rioting. One battle plan 
was revealed at a press conference in New York on June 29 by the National Mobilization Committee to End the War in Vietnam... "We are planning tactics of prolonged direct action to put heat on the government and its political party," Hayden told the radical weekly Guardian. In the vocabulary of the new left, "direct action" can include street barricading, fire bombing, seizure of buildings, and mass attacks on the police (Fortress Chicago, p.20).

Again the message is that the protestors are outsiders who deliberately planned to invade Chicago and disrupt not only the convention but the lives of Chicagoans. This theme of a threat to social order by outsiders was used repeatedly to justify and defend the actions of the police. This was illustrated when Mayor Daley said, "I would like to say here and now that this administration and the people of Chicago have never condoned brutality at any time, but they will never permit a lawless, violent group of terrorists to menace the lives of millions of people, destroy the purpose of this national political convention, and take over the streets of Chicago" (Schreiber, August 30, 1968, p. 4).

The Tribune reported that "a large majority of the hundreds of people telephoning THE TRIBUNE yesterday in the wake of street rioting praised Mayor Daley and the Chicago police" (Most callers, August 30, 1968, p.12). The article reported in greater detail the support expressed.

Mrs. Alice Green, chief operator at City hall reported 11 operators received more than 8,000 calls during the peak period between 9:30 and 11:30 a.m. yesterday. She said most praised Daley and the police. A tabulation of 500 telegrams received by the mayor's office is was reported showed 90 percent favorable to the mayor and police. Most telegrams of condemnation came from California and New York, a spokesman said. (Ibid)

The Tribune ran several more articles that emphasized the support for the Mayor and the police in their attempts to restore the social order that was threatened by outsiders. Most notably was the praise from Vice President Humphrey.

'I think Chicago received some very unfair publicity', the Presidential hopeful said just before he boarded his chartered flight at O'Hare airport. 'I love Chicago. It's my kind of town. I want to say to the people of Chicago just a word. I thought the people 
here were very hospitable. They were wonderful hosts and whatever happened here that was unfortunate and unhappy is not due to the people of this city. I think the people here have the right to feel that they did a good job and they were the kind of neighbors that make all of us proud. Whatever trouble took place here was imported.' (Maclean, August 31, 1968 p.5)

This framing of the trouble being imported from outsiders or non-Chicagoans was further developed in the stories that reported the number of arrests made during the protests. The subheading of one article read, "Large Minority from Out of Town" (Name Persons, August 30, 1968, p.9). It reported that of 309 people arrested 136 gave out-of-town addresses and 173 gave addresses in Chicago or its suburbs. Despite the majority being local the heading stressed the out of town angle. In another article the non-local angle is also emphasized, when it reported that of 568 arrests 170 were not Illinois residents with two from Canada, one from France, and one from England (2,000 Flee to Park, August 30, 1968, p. 9)

When the protests had ended, the Tribune ran a story on August 30, 1968 entitled, "City Returns to Calm of Pre-Yippie Days." This story reported that, "The police department reported that 583 persons were arrested in connection with the invasion of yippies last weekend and subsequent clashes with the police. One hundred eighteen policemen were injured during the Democratic national convention week... The police department went back to normal eight-hour shifts and resumed regularly scheduled days off' (p.11). This article symbolized the end of the invasion and the success of the police in restoring order. In recapping the events of the last week in this article, the emphasis was on the social disorder and injury to police caused by the invasion and the successful restoration of order by the police.

In examining the protest coverage in the Chicago Tribune during the 1968 Democratic Convention it is clear that the protest paradigm was used. However, as the host city for the convention, the articles in the Chicago Tribune further developed the narrative structure of battle and social disorder to include the frame of invasion by outsiders. Having established this frame as being present in the Chicago Tribune during the 1968 Convention, the New York Times during the 2004 Republican Convention will be examined next. 


\section{The New York Times-2004}

The coverage in the New York Times paralleled the coverage in the Chicago Tribune in 1968. As the hometown newspapers for the host cities, the coverage of the protests is very similar. Prior to the start of the convention and the protests, each of these papers ran stories about the legal battles being fought in the courts by the protestors in regards to permits to hold rallies and marches. Just as the protestors in Chicago had been denied permits to march and protest in the park, so too were the protestors in New York City. The Times ran articles detailing the legal battle surrounding the requests by protestors to assemble in the park and the denial of these requests. One reason cited for the denial was concern for the preservation of the lawn.

In the days leading up to the 2004 Republican convention in New York the stories in the New York Times also set the stage for the anticipated conflict between the protestors and police through comparisons with the 1968 Democratic convention, as well as the protests at the 1999 WTO conference in Seattle. Like the Tribune in 1968, the Times ran stories about how welltrained and prepared the police were for the anticipated conflict. The Times also reported the concerns of New Yorkers leading up to the convention.

New Yorkers in general seem to be bracing for the convention with all the enthusiasm normally reserved for a trip to a dentist. Two opinion surveys made that point yesterday. One by Quinnipiac University, said that 50 percent of city voters were worried about next week's doings; only 14 percent were excited. Similarly, half of the New Yorkers in a New York Times/CBS News poll worried about a possible terrorist attack and about violence resulting from street protests. They said they wished the Republicans had taken their show somewhere else (Haberman, August 27, 2004, p.1)

However, unlike Chicago in 1968, as the convention and protests began, the much anticipated violent conflict did not occur. Throughout the course of the convention, the majority of the thousands of protestors marched peacefully and without incident.

Since there was little violence to cover, the narrative structure of the stories shifted from an emphasis on violence to an emphasis on the threat to the social order. This was often accomplished through a focus on the disruptions to everyday life for New Yorkers that were created by the protestors. Stories in the Times referenced opinion surveys of New Yorkers and interviewed bystanders to convey cues to public opinion about the protestors. For 
example, interviews with bystanders focused on the inconveniences the protestors had created for New Yorkers as a result of closed streets. The article headlined, "Outward Calm Attests to Disruption of City" addressed the impact the convention and protestors had on the city.

Emptier-than-normal commuter trains whisked through intensified security yet pulled into the city largely on time. New Yorkers unable to finagle the week off endured bomb-sniffing dogs and squads of inquisitive police officers in thickly guarded Midtown Manhattan. Political agitators howled their dissent but kept their protests from raging into violence. As the visiting Republicans began to carry out their ordained business on the opening day of the Republican National Convention yesterday, the city awoke and dispensed with its own business with determined complacence, as if nothing more than the Jaycees were in town. For the most part, people uncomplainingly tolerated the expanse of closed streets and insistent and pervasive security details. The morning rush was remarkably light given the previous weeks of warning, with some commuters getting to work earlier than normal because of reduced passenger loads. Businesses, though, lamented what they found to be subdued traffic, and those making deliveries faced a fair amount of travail. The New York Stock Exchange recorded its lightest trading day of the year. The outward, seemingly unruffled calm of the day, in a sense, spoke to how disruptive the convention actually was to the city's entrenched rhythms. Warned and warned again about the perils and peculiarities of the first-ever Republican convention in this stubbornly Democratic city -- and in an age of heightened terrorism -- many New Yorkers reconfigured their routines, staying home from work, fleeing the city, closing businesses, all to sidestep potential chaos or simple annoyance.(Kleinfield, Aug. 31, 2004, p. 1)

Coverage also focused on the violation of laws by the protestors which provided further evidence of their threat to the social order. Just as Mayor Daley had in 1968, Mayor Bloomberg cautioned that disruption to the social order through the violation of laws would not be tolerated

Mayor Michael R. Bloomberg, speaking at a news conference at Shea Stadium, said that the city welcomed those who wanted to express themselves but that no one would be permitted to do so at the cost of other people's liberties. "And anybody else that thinks that they're going to get free ride here in New York City in breaking the law, 
they are sadly mistaken. We are going to enforce the law," he said. "And I would just advise anybody that thinks they're going to use any part of today to cause disruption, and to cause chaos, they should think again. They're going to be arrested instantly." (Rashbaum \& Wilson, Sept. 1, 2004, p.7)

The articles in the Times made it clear that the police were responsible for maintaining the social order and minimizing the disruptions as much as possible. There were arrest accounts of those who blocked streets or strayed from pre-approved march routes. The use of orange netting similar to snow fencing by the police to round up people and minimize injuries was also reported. There was some criticism of the detention time of protestors who had been arrested, but most of the coverage of the police action was favorable. Like the Tribune in 1968, the Times was supportive of the police and their efforts to maintain order. In recounting the events of the week, the Times reported that,

The arrests and rallies were a coda to a week in which protests veered from the benign to the chaotic, from dropping banners and heckling delegates to blocking sidewalks and streets and occasionally scuffling with the police. To patrol the week's protests, which were the largest in the history of political conventions, the Police Department mobilized nearly its entire 37,000-member force, and flooded the streets around the Garden and delegate functions with officers, some in helmets and toting batons, some in plain clothes closely watching suspected troublemakers. Officers moved in swiftly at the slightest flare-up of lawbreaking and managed to contain demonstrations large and small with little violence, though many people complained that large numbers of bystanders had been unjustly arrested. (Archibold, September 3, 2004 p. 8)

Despite the largest protests in the history of political conventions, the police were able to contain the threat to the social order posed by these protestors. Mayor Bloomberg and other officials were also quoted in articles crediting the police and their training for the mostly peaceful, uneventful marches that occurred.

The reliance by journalists at the Times on Mayor Bloomberg and other officials, such as police spokesperson, Paul J. Brown, in many of the stories resulted in support of the status quo by allowing the official sources to define the perspective of the stories. An example of this is in how the protestors were framed. 
As Mayor Daley had done in 1968, Mayor Bloomberg and other officials in 2004 framed the protestors as outsiders. At a news conference on August 31, 2004, Police Commissioner Raymond W. Kelly was quoted as saying,

I also want to note that many of those arrested are from out of town and are veterans of other demonstrations in cities with much smaller police departments. In the past, a few got arrested and most got away after breaking the laws. Here they are being surprised by the fact that the opposite holds true (Rashbaum \& Wilson, Sept. 1, p.7)

This quote which appeared in an article headlined, "Barricades Help Officers Keep Crowds Controlled", underscored that violations of laws, particularly by outsiders who sought to threaten order would not be tolerated and that the police would maintain the order. The framing of the protestors as outsiders was further evidenced when it was reported on September $3^{\text {rd }} 2004$ that, "The Bloomberg administration has been suggesting in recent days that most of those arrested came from outside New York. Of 1,735 people arrested who gave their names -- 61 have refused -- 600 live in New York State and the rest outside, though the police did not say how many were from New Jersey or Connecticut"(p. 8).

Mayor Bloomberg and other officials were even quoted as referring to the protestors as anarchists. As reported by Randal C. Archibold on September 3, 2004, verbal harassment of delegates on the streets and at their convention functions led Mayor Bloomberg to draw parallels between the protestors and terrorists.

It is true that a handful of people have tried to destroy our city by going up and yelling at visitors here because they don't agree with their views," Mr. Bloomberg said. "Think what that says. This is America, New York, cradle of liberty, the city of free speech if there ever was one and some people think that we shouldn't allow people to express themselves. That's exactly what the terrorists did, if you think about it, on 9/11. Now this is not the same kind of terrorism but there's no question that these anarchists are afraid to let people speak out" (p.8).

Although the protestors in 1968 were referred to as terrorists by officials, being called a terrorist in post 9/11 America takes on new meaning. Not only were the protestors labeled as outsiders, but they were further distanced from New Yorkers by being compared to terrorists. 
This attempt to frame the protestors as outsiders who had invaded New York seems to have been accepted by some as evidenced by Deb Etcheson, an alternate delegate from Iowa. She is quoted as saying, "A person came by and used an explicative and stuck his finger in our face. But I don't blame that on New Yorkers. I just love this city (Archibold, August 31, 2004, p. 12).

Although there are similarities in the ways that the hometown papers of the host cities covered the protests, there are also some notable differences. One of the differences is that in the New York Times the theme of the city being invaded by outsiders is not limited to the protestors. The Republican National Convention and its delegates are also framed as part of the invasion of outsiders that has disrupted the order of New York City. Unlike The Tribune in 1968 that embraced the convention and its participants, the Times in 2004 included articles that expressed public opinion that was less than enthusiastic about the convention and that reported the disruption to the flow of life in New York City as a result of the presence of the convention participants and protestors. Although the Republican National Convention may have been the invited guests of Mayor Bloomberg, the articles in the Times made it clear that they were not welcome by all New Yorkers.

As an anticipated 50,000 delegates, demonstrators and others land in New York City this weekend for the Republican National Convention, the four-day extravaganza opening Monday at Madison Square Garden, half of all New Yorkers are approaching the week with a mix of dread and unease, like reluctant hosts wishing the party were in someone else's house. Fifty-three percent of city residents say they are very or somewhat worried that a terrorist attack will happen during the convention, according to a New York Times/CBS News poll. Forty-eight percent say they are very or somewhat worried that demonstrations or protest marches will lead to violence. Fiftytwo percent said some other city should have been picked to hold the convention...Some New Yorkers said they were planning to be out of town during the convention: Eighteen percent of Manhattanites polled and 13 percent of people citywide said they were expecting to be gone. It was unclear how many would have done so without the convention. Others said in interviews that they worried about the expense of the convention, the disruption, the anxiety. "I'm a New Yorker all my life," said Marida Sapichino, who lives in Midtown Manhattan and runs a publishing company in New Jersey. "And when I hear that cabs are not going to be working next 
week and subways are going to be scarce, it's like, what's going on with my city here? My city is now being taken over by fear." (Scott and Connelly, Aug. 27, 2004, p.1)

The order or flow of life for New Yorkers had been disrupted by the invasion of outsiders, both delegates and protestors, into the City who were not welcome by many. Like the Tribune in 1968, the Times incorporated the theme of an invasion of outsiders into the host city as a result of the convention. However, the Times expanded this theme to include the convention delegates as part of the invasion. In doing so, the Times was less supportive of the establishment and status quo then the Tribune had been in 1968. Rather than embrace the RNC, the Times acknowledged that they were part of the problem.

Another way that the Times differed from the Tribune in 1968 was in the number of articles that allowed the protestors to speak for themselves. The Tribune ran very few articles that quoted protestors and instead relied heavily on official sources. Although the Times did rely on official sources, it also ran a number of articles that quoted protestors. The articles emphasized the experiences of the protestors including their travel to New York, getting arrested, infiltrating the convention and hanging banners. Unfortunately, this type of coverage which emphasized events rather than issues did little to help foster an understanding of the protestors. Some of the coverage also deligitimized the protestors through an emphasis on appearance, disorganization and lack of leadership. For example, on August 29 Cardwell reported that, "As protest organizers scrambled through the last week of preparations, two major themes emerged: the leadership of the protest effort is deeply fractured, and the many groups flooding New York's streets are poorly coordinated and under no central control" (p.27).

Although the Times attempts to be balanced in its coverage by including articles about the protestors that allow them to speak for themselves, the result is not always a deeper understanding. By emphasizing events rather than issues, the coverage is not as balanced as it could be. By relying on the protest paradigm many of the articles actually delegitimize and marginalize the protestors resulting in support for the status quo. 


\section{The STAR TRIBUNE- 2008}

Like the New York Times in 2004 the articles in the Star Tribune in 2008 are event focused rather than issue focused. The coverage included accounts of the activities of the protesters and the police. Articles detailed the various protest marches including the numbers of people arrested as well as the attempts of the protestors to work within the law and the restrictions given them. A few stories also reported on how the police had prepared and trained for the influx of protestors. Chanen reported that, "Officers had practiced military formations, drilled with mounted and bike patrols, and worked on how to arrest a person who is resisting (Close Encounters, 9/6/08, p.03B) Although some military terminology like skirmish and showdown can be found in a few of the stories and incidences of violence are reported, the violent battle theme is not prevalent.

Interestingly, the protestors are not the only ones accused of violent acts, so too are the police. Traditionally, police action is framed not as violence, but as an effort to maintain or restore social order. For example, it was reported that the national guard was called in "to help maintain order in some parts of St. Paul, and more than 280 people were arrested in showdowns with police or for acts of vandalism (For GOP, Diaz, 9/2/08, p. 01A). However, in some of the articles the actions of the police were framed as violence as well. Prior to the start of the convention the police conducted raids according to officials to prevent "anarchists" from perpetrating violent acts and disrupting the order (Police raids, Estrada et. al, 8/31/08, p. 14A). In the articles about the raids as well as other articles about the actions of the police, officials called the actions of the police justified. For example as reported by Chanen, "Although some concertgoers later complained of "police overkill," and 800-plus arrests recorded during the convention week has drawn criticism, authorities said the show of force was purposeful and appropriate. Capt. Ed Frizell, a commanding officer at the Target Center concert said, "If we need to protect the city, we will go hard." "Said St. Paul police commander Doug Holtz: 'We're telling the citizens of St. Paul: You look at the footage, you look at the actions of these criminals, and you tell me as a citizen that these actions were lawful and that the police didn't act appropriately" (Security or repression? Furst and Lonetree, 9/4/08, p. 01S). However, the official's attempt to frame the events and the actions of the police were not allowed to stand alone. The articles also quoted protestors and others who questioned and criticized to the actions of the police. "Randi McClure, 23, said, she was one of about 10 people handcuffed and made to lie face down at gunpoint by police... She 
was not arrested. 'Everyone I know who's protesting is going to be peaceful,' she said. 'I think the violence is caused by the cops" (Police raids, Estrada et. al, 8/31/08, p. 14A). Some protesters even accused the police as the ones that were the threat to order.

Shamako Noble, president of Hip Hop Congress in San Jose and a member of the group that organized the peaceful Poor People's March on Tuesday that included about 2,000 people noted that hundreds of officers in riot gear lined the streets as they marched. He said that their demeanor, with tear-gas guns at the ready, seemed to escalate the situation rather than calm it. He noted that marshals from his own group successfully policed their march, getting protesters who shouted at police to move along (Security or repression? Furst and Lonetree, 9/4/08, p. 01S).

However, both officials and protesters identified a minority group of protesters as anarchists who were seen as threatening violence and posing a threat to the order. Kersten reported that, "Anarchists have been threatening to "shut down" both the convention and the Twin Cities" (Here's a protest, 9/1/08, p. 04S). The mayor welcomed those who had come to peacefully express their rights and warned those who planned to be disruptive. "Protecting lawful protesters is a key factor behind the raids. 'We are making sure that people here to legitimately protest have the right to do that', St. Paul Mayor Chris Coleman said. 'When people come down to protest in the peace march, we don't need their public and personal safety threatened. It's just absolutely imperative that all the peaceful protesters have a chance to do that '(Setbacks, Brown, 9/1/08, p. 03S). The protestors were also critical of the 'anarchists.' During a rally in Mears Park, “at one point, event organizer, Cheri Honkala of the Poor People's Economic Human Rights Campaign urged the crowd not to let the anarchists "hijack" the event" (Marches continue, Estrada et al, 9/3/08, p. 04S).

The break from a reliance on official sources in these stories represents a change from the template of the protest paradigm. Although a fair number of articles quoted the mayor, the police chief and other officials, the articles often balanced this with quotes from protestors and others. Because of a reliance on a variety of sources, the articles were less supportive of the status quo. Protest leaders and organizers were able to speak for themselves and offer their perspective. This is quite different from the coverage in 2004 that helped to delegitimize the groups through an emphasis on a lack of organization and leadership. The Star Tribune contained articles that actually highlighted the organization of the protest groups and their 
attempts to work within the establishment to plan their protests. For example, Estrada reported that, "A big concern of the antiwar demonstration leaders and their lawyers was that the route given to them by St. Paul police was too narrow, the turn-around in front of the Xcel Energy Center was too abrupt, and they would not be able to be clear of the $X$ by $4 \mathrm{pm}$, the deadline mandated to them by police" (Free speech, 9/2/08, p. 06S). This reflected the concern the demonstration leadership had in working within legal boundaries. Since a variety of perspectives including those of the protesters were provided in the stories the officials were unable to dominate the framing of the events. By quoting a variety of protest leaders and organizers, the articles also provided evidence of leadership of the protests and helped to legitimize some of the protest groups.

There is actually little evidence of the characteristic of the protest paradigm of framing the protestors as deligitimate, marginal or deviant. Overall, there is general support for the protestors in that there were many stories that allowed protestors to speak for themselves in coverage that seemed to be more balanced than usually found when the protest paradigm is used. The exception is when a minority of protestors labeled as anarchist were discussed. Simply labeling these protestors as anarchists frames them as deviant. However, it should also be noted that some of these people were self described anarchists. Basically, two groups of protestors are included in the coverage, the peaceful ones, who were the majority, and the anarchists. Officials identified the deviance and threat of the anarchists. Quoting peaceful protestors' opposition and discontent with the anarchists also helped establish the anarchists as the deviant minority. For example, Cheri Honkala, a leader of the Poor People's Economic Human Rights Campaign, “appealed to rally participants to be nonviolent, pointing out that there were children in the crowd. She told anarchists intermingled in the crowd that she would hold them responsible if they interfered in the peaceful march (2,000 rally, Furst, Brown \& Estrada, 9/3/08, p.04S).

Although some elements of the protest paradigm are present in some of the stories in the Star Tribune, in general the stories deviate from the template of the protest paradigm. Unlike the New York Times in 2004, the Star Tribune does not invoke public opinion by referencing opinion polls and surveys. Reference to public opinion was included in the stories through interviews with a variety of people as well as the published letters to the editor. What was included did not indicate a majority opinion in opposition to the protestors. For example, 
Tony Bouza said that, "most of the protesters including those who engaged in peaceful civil disobedience are patriots...they are the ones fighting for the Constitution" (Massive show of force, Furst and Lonetree, 9/6/08, p. 01B).

The Star Tribune's coverage also breaks from the protest paradigm by not relying solely on official sources and definitions. As noted, a variety of sources including the mayor, other officials, protestors, leaders, organizers and community leaders were cited. This practice allowed for a variety of perspectives to be presented and the officials were not able to monopolize the framing of the events. There was also less evidence of framing the protestors as deligitimate, marginal and deviant. Only those labeled as anarchists were presented as deviant and a threat to the social order. The threat to the social order through an invasion of outsiders disrupting everyday life was not as prominent in the Star Tribune as it was in the New York Times. Only a few articles made reference to the inconveniences and disruptions created by the protestors and the convention with one referring to it as "the Siege of '08")(Ah, fond memories, Coleman, 9/5/08, p. 07S).

Based on this analysis it would appear that a change has occurred in the way that the press covered protestors at the 2008 Republican national convention compared to 2004. In 2004 the New York Times utilized the protest paradigm in its coverage of the protests. In doing so, the New York Times was supportive of the status quo and framed the protestors as outsiders who had invaded their city and disrupted the order. Four years later the Star Tribune varied from the template provided by the protest paradigm. Additionally, the Star Tribune did not frame the protestors as invaders who threatened the social order.

\section{Conclusion}

As hometown papers for the host cities of national conventions during times of war protests, the Chicago Tribune in 1968, the New York Times in 2004 and the Star Tribune in 2008 had similarities and differences in their coverage of the protestors. Each paper utilized elements of the protest paradigm to varying degrees in the construction of their stories about the protests. Additionally, this study found that the Chicago Tribune and the New York Times developed the theme of an invasion of their respective cities by outsiders who threatened the social order. The newspapers emphasized the threat to social order poised by the protestors through reporting on violation of laws and disruption to everyday lives of city residents. 
These papers also emphasized the role of the police in maintaining or restoring the order. Although similarities were found, there were some key differences found between these two papers. The New York Times ran more stories about the experiences of the protestors allowing them to speak for themselves. The stories in the New York Times also treated the Republican National Convention and its delegates as part of the invasion of outsiders threatening the social order.

As the site of the 9/11 tragedy, New Yorkers were particularly sensitive to any disruption to the social order. Therefore, the inclusion of the RNC as part of the invasion and problem may have been a result of this. It is also possible that many New Yorkers did not welcome the Republicans since New York is considered to be largely democratic.

As has been demonstrated the New York Times utilized the protest paradigm in its coverage of the protests during the 2004 Republican National Convention. Of significant note is that four years later the Star Tribune varied from the template provided by the protest paradigm in its coverage of the protestors during the 2008 National Convention and was less supportive of the status quo. In allowing a variety of perspectives to be presented the Star Tribune presented the peaceful protestors as legitimate. In the year that promised change, it would appear, at least in the case of the Star Tribune, that groups promoting it were acknowledged by the press. 


\section{References}

2,000 Flee to Park, August 30, 1968, The Chicago Tribune, p. 9.

800 Guardsmen Face Hippies in Park, August 28, 1968, The Chicago Tribune, p. 1.

Archibold, Randal C., August 31, 2004, The Republicans: The Convention in New YorkConfrontations, The New York Times, p. 12.

Archibold, Randal C., September 3, 2004. The Republicans: The Convention in New YorkDemonstrations, The New York Times, p.8.

Bad Judgment by the Police, August 28, 1968, The Chicago Tribune, p. 16.

Brasted, Monica (2005). Framing Protest: The Chicago Tribune and the New York Times during the 1968 Democratic Convention. Atlantic Journal of Communication, 13 (1), $1-25$.

Brasted, Monica (2005). Protest in the Media. Peace Review: A Journal of Social Justice, 17: 383-388.

Brown, Curt. September 1, 2008. Setbacks don't dampen protesters' fervor. Star Tribune (Minneapolis, MN), p. 3S.

Cardwell, Diane, August 29, 2004. Campaign 2004: Tactics, The New York Times, p. 27.

Chan, J.M. \& Lee, C.C. (1984). The journalistic paradigm of civil protests: A case study of Hong Kong. In A. Arno \& W. Dissanayake (Eds.) The news media in international and national conflict (p.183-202). Boulder, CO: Westview.

Chanen, David. September 6, 2008. CLOSE ENCOUNTERS EN FORCE, Star Tribune (Minneapolis, MN), p. 3B.

City Returns to Calm of Pre-Yippie Days, August 30, 1968. The Chicago Tribune, p. 11.

Coleman, Nick. September 5, 2008. Ah, fond memories: Riot gear, anarchists and the GOP. Star Tribune (Minneapolis, MN), p. 7S.

Diaz, Kevin. September 2, 2008. FOR GOP, A DAY OF DISTRACTIONS; PROTESTS. Star Tribune (Minneapolis, MN), p. 1A.

Entman, R. (1993). Framing: Toward clarification of a fractured paradigm. Journal of Communication 43 (4), 51-58.

Estrada, Heron, Randy Furst and Curt Brown. September 3, 2008. Marches continue, but violence ebbs. Star Tribune (Minneapolis, MN), p. 4S.

Estrada, Heron, Randy Furst and Curt Brown. September 3, 2008. 2,000 rally to `stop war on the poor'. Star Tribune (Minneapolis, MN), p. 4S. 
Estrada, Heron Marquez. September 2, 2008. Free speech gets silent treatment. Star Tribune (Minneapolis, MN), p. 6S.

Estrada, Heron, Bill McAuliffe and Abby Simons. August 31, 2008. Police raids enrage activists, alarm others. Star Tribune (Minneapolis, MN), p. 14A.

Fortress Chicago, August 29, 1968. The Chicago Tribune, p. 20

Furst, Randy \& Anthony Lonetree. September 6, 2008. Massive show of force fits the trend. Star Tribune (Minneapolis, MN), p. 1B.

Furst, Randy \& Anthony Lonetree. September 4, 2008. PROTEST ARRESTS; Security or repression? Star Tribune (Minneapolis, MN), p. 1S.

Gitlin, Todd, (1980). The whole world is watching. Mass media and the making and unmaking of the New Left. Berkeley, University of California Press.

Goffman, Erving, (1974). Frame Analysis, Boston: Northeastern University Press.

Haberman, Clyde, August 27, 2004, Even Protesters Ignore Queens, And It Shrugs, The New York Times, p. 1.

Kersten, Katherine. September 1, 2008. Here's a protest you probably didn't expect to see in St. Paul. Star Tribune (Minneapolis, MN), p. 4S.

Kleinfield, N.R., August 31, 2004, Outward Calm Attests to Disruption of City, The New York Times, p.1.

Maclean, August 31, 1968, The Chicago Tribune, p. 5.

McLeod, Douglas M. (1995). “Communicating Deviance: The Effects of Television News Coverage of Social Protest.” Journal of Broadcasting \& Electronic Media (39): 4-19.

McLeod, Douglas M., and Benjamin H. Detenber. (1999). "Framing Effects of Television News Coverage of Social Protest.” Journal of Communication (3): 3-23.

McLeod, Douglas M., and James K. Hertog (1992). The manufacture of public opinion by reporters: Informal cues to for public perceptions of protest groups. Discourse and Society, 3, 259-275.

Most callers praise Daley for tough stand on rioters, August 30, 1968, The Chicago Tribune, p.12.

Name Persons, August 30 1968, The Chicago Tribune, p. 9.

Norris, P. (1995). The Restless Searchlight: Network News Framing of the post-Cold War World. Political Communication, 12, 357-370.

Rashbaum, William \& Michael Wilson, September 1, 2004. The Republicans: The Convention in New York-The Police, The New York Times, p. 7. 
Schreiber, Edward. Daley Blasts 'Suppression of the Czechs', August 23, 1968 The Chicago Tribune p. 11.

Schreiber, Edward. August 30, 1968, Terror Mob Periled City, Mayor Says, The Chicago Tribune, p. 4.

Scott, Janny \& Marjorie Connelly, August 27, 2004, New York Awaits Republicans with Reluctance and Unease, The New York Times, p. 1.

Tarrow, Sidney. (1994). Power in Movement: Social Movements, Collective Action and Politics. New York: Cambridge University Press.

Tuchman, Gail. (1978). Making News. New York: Free Press.

Weidrich, Robert. Seize Dope Cached for Hippies, August 221968 The Chicago Tribune, 1A, p. 3 